\title{
PI3K class II $\alpha$ : a novel regulator of vesicular trafficking at the base of the primary cilium
}

\author{
I Franco ${ }^{1 *}$, F Gulluni ${ }^{1}$, C Costa ${ }^{2}$, JP Margaria ${ }^{1}$, CC Campa ${ }^{1}$ E E De Luca ${ }^{1}$, D Monteyne ${ }^{3}$, D Pérez-Morga ${ }^{3}$, A Boletta ${ }^{4}$, \\ A Ranghino ${ }^{5}$, GR Merlo $^{1}$, E Hirsch ${ }^{1}$ \\ From First International Cilia in Development and Disease Scientific Conference (2012) \\ London, UK. 16-18 May 2012
}

The class II phosphoinositide 3-kinase PI3K-C2 $\alpha$ is a protein of the early endocytic compartment and the transGolgi network. It produces PtdIns-3-P and is characterized by a clathrin-binding site which confers to this enzyme an important role in modulating clathrin distribution and activity in the cell. However, implication of PI3K-C2 $\alpha$ in the primary cilium biology has never been described. Through the generation of a Pik3c2a knock-out mouse strain, we discovered that PI3K-C2 $\alpha$ was fundamental during embryonic development and that its loss conferred features of ciliopathy. In particular, homozygous mutant embryos died at midgestation and displayed laterality defects and impaired Hedgehog signaling, while heterozygous adults showed renal cysts susceptibility after kidney injury. Cilia of Pik3c2a deficient embryos were shorter and swollen and displayed a defect in accumulating Smo and Polycystin-2. In primary mouse embryonic fibroblasts, PI3K-C2 $\alpha$ was highly enriched on vesicles at the basal body of primary cilia. In Pik3c2a-deficient cells, absence of the protein specifically caused a reduction of vesicular trafficking at the cilium base, suggesting that PI3K-C2 $\alpha$, through its ability to recruit clathrin and produce PtdIns$3-\mathrm{P}$, is required for the correct exchange of structural proteins and signaling molecules between the cilium compartment and the cytoplasm. Thus, our data indicate PI3K-C2 $\alpha$ as a novel regulator of vesicular trafficking at the base of the primary cilium.

\footnotetext{
Author details

${ }^{1}$ Molecular Biotechnology Center, University of Torino, Italy.

${ }^{2}$ Massachusetts General Hospital Cancer Center, Harvard Medical School, USA. 'aboratoire de Parasitologie Moléculaire, Institut de Biologie et de Médecine Moléculaires (IBMM), Université Libre de Bruxelles,Belgium.
}

\footnotetext{
* Correspondence: frirene85@yahoo.it

${ }^{1}$ Molecular Biotechnology Center, University of Torino, Italy

Full list of author information is available at the end of the article
}

${ }^{4}$ Dulbecco Telethon Institute, Dibit San Raffaele Scientific Institute, Italy. ${ }^{5}$ San Giovanni Battista Hospital, University of Torino, Italy.

Published: 16 November 2012

doi:10.1186/2046-2530-1-S1-P67

Cite this article as: Franco et al: PI3K class II $\alpha$ : a novel regulator of vesicular trafficking at the base of the primary cilium. Cilia 2012 1(Suppl 1):P67.
Submit your next manuscript to BioMed Central and take full advantage of:

- Convenient online submission

- Thorough peer review

- No space constraints or color figure charges

- Immediate publication on acceptance

- Inclusion in PubMed, CAS, Scopus and Google Scholar

- Research which is freely available for redistribution

Submit your manuscript at www.biomedcentral.com/submit

\section{() Biomed Central}

